International Journal of Business Management and Economic Review

Vol. 3, No. 01; 2020

ISSN: 2581-4664

\title{
THE EFFECT OF LEADERSHIP CAPACITY, RESOURCE DESTINATION MICE TO MICE DEVELOPMENT AND ITS IMPACT ON REGIONAL ECONOMIC GROWTH IN MEKONG DELTA PROVINCES, VIETNAM
}

\author{
Master. Nguyen Van IT \\ Ho Chi Minh City University of Food Industry, Vietnam \\ Prof. Phd. Hoang Thi Chinh \\ University of Economics - Finance, Hochiminh City, Vietnam \\ http://doi.org/10.35409/IJBMER.2020.3156
}

\begin{abstract}
This study is to test the effect of leadership capacity, resource destination MICE to MICE development and its impact on regional economic growth. The author used the survey method by distributing a sample survey to collect primary data from the houses directly leading the MICE tourism business and the leaders of the department of tourism in the Mekong delta provinces, Vietnam with a sample number of 399 during the 60 days from early July to September 2019. Then conducted statistical analysis with SPSS22.0, AMOS 22.0 software through steps such as analysis coefficient Cronbach's AlphaExploratory Factor Analysis (EFA), Confirmatory Factor Analysis (CFA) and Structural Equation Modeling (SEM). The research results contribute both theoretically by the empirical proof of the research model with statistical significance and in terms of practical significance as a basis for MICE tourism business leaders and leaders. Department of tourism leaders have appropriate solutions to leadership capacity, resource destination MICE, to promote MICE development and its impact on regional economic growth.
\end{abstract}

Keyword: leadership capacity; resource destination MICE; MICE development; regional economic growth.

\section{INTRODUCTION}

Tourism plays an important role in achieving economic development goals, and it also plays a part in realizing social, environmental and human development goals (Harrison, 2015). Tourism development in a destination depends on both natural cultural and other intangible, tangible resources. Tourism development in addition to increasing opportunities for visitors to meet the needs of enjoying quality products and services from the resources of stakeholders in the destination, the tourism industry also needs to protect cultural values and the extremely valuable traditional value system of local and national resident communities.

As an emerging service industry, the MICE (Meeting, Incentive, Convention and Exhibition) industry will be important focused and researched for its widely influence surface, highly correlation, This is a type of tourism combining conferences, seminars, awards and events, bringing a value of revenue 6 times higher than conventional tourism. With many advantages blessed by nature, the provinces of the Mekong Delta have many opportunities to become a 


\section{International Journal of Business Management and Economic Review}

Vol. 3, No. 01; 2020

ISSN: 2581-4664

thriving Mice tourism type. In recent years, the number of domestic and international Mice visitors has been constantly increasing. According to the experts of tourism, compared to other countries in the region such as Singapore, Thailand, Malaysia, the provinces of the Mekong Delta, Vietnam is a market with outstanding potential for tourism development Mice.

The development of MICE industry promotes the formation of new economic form, namely MICE economy. The MICE economy is a comprehensive economy, which through holding various forms of conference and exhibition, conveying information, providing services, creating business opportunities based on MICE industry, and improving to traffic, communication, hotel, retail, catering, tourism, advertising,printing, decoration, logistics, freight and other related industries because of its correlation effect.

\section{LITERATURE REVIEW}

\subsection{Leadership capacity}

Competency framework is defined as a tool to identify the knowledge, skills, qualities and behavioral behaviors needed to be able to effectively perform work in an organization (Koenigsfeldet al., 2012). Competency framework is usually presented in the form of a table describing a combination of knowledge, skills, attitudes and characteristics of an individual to complete a job. There are 5 capacity frameworks: capacity for industry, field, organization, job position and individual. In this study, we approach a sectoral competency framework typical of Vietnam's new tourism industry and build on Bass's ASK model (Bass,1990) including: leadership knowledge, leadership skills and attitude leader.

\subsection{Resource destination $\mathrm{MICE}$}

According to Dwyer et al. (2007), MICE is an area of supply and demand for the event, using a venue for a minimum of half a day with the purpose of encouraging the participation of many people, conduct businesses, share ideas, study or socialize. A MICE tourism activity often involves many business organizations and related organizations (McCabe et al., 2000). These organizations are either in the destination or outside the destination, they bring resources to work in a specific destination. The resources that can be put into operation include infrastructure, equipment, service providers, attractions, technological processes, human resources, knowledge, experience, and relationships... For MICE to work well, it is necessary to have the participation of many participants such as transportation, hotels, convention centers, exhibition centers, media, audiovisual, eating, drinking, and entertainment knowledge, shopping(Dwyer et al., 2001).According to Acedo et al. (2006), research on resources includes: Resource-Based View; Knowledge-Based View and Relational View.

In this study, the author approaches destination resources in the direction of Mills et al. (2003). The resources include two internal resource groups such as heritage cultural resources, destination environmental conditions and groups. External resources such as suppliers, organizations and visitors resources.

\subsection{MICE Development}

A MICE tourism activity often involves many business organizations and related organizations (McCabe et al., 2000). These organizations are either in the destination or outside the destination they bring resources to work in a specific destination. Resources that can be put 


\section{International Journal of Business Management and Economic Review}

Vol. 3, No. 01; 2020

ISSN: 2581-4664

into operation include infrastructure, equipment, service providers, attractions, technological processes, human resources, knowledge, experience, and relationships. .. From Fan, $\mathrm{H}$. (2017)realize that the MICE tourism development is: i) The increase in profits for local businesses through the amount of visitors' spending in restaurants drinking, shopping, entertainment ...; ii) Through the above revenue, MICE tourism has contributed directly and indirectly to the government budget; iii) Create more jobs at enterprises that are suppliers or intermediaries providing services; iv) Stimulate increased investment in both public and private sectors in tourism and entertainment infrastructure to meet the increasing demands of tourists for the quality of services and v) Maintain the quality of environment. Thus, the increase in development is both an incentive for organizations and businesses to increase investment in resources, skills and qualifications of workers, and stimulate relevant supporting industries to participate in the supply chain. MICE travel products to provide quality, diverse travel products. Through these products brings greater revenue for organizations, businesses and the economy.

Therefore, in this study, the author approached MICE tourism development in a sustainable manner with three angles: i) Environment; ii) Economics and ii) Social culture.

\subsection{Relationship between Leadership capacity, Resource destination MICE, MICE Development and Regional economic growth}

From the influence relationship of leadership and tourism development MICE, Gregorić (2014); Sylla et al. (2015) pointed out the need for strategic investment in MICE tourism, improved infrastructure, good transportation access, high standards of tourist accommodation, and infrastructure. MICE activities and a number of factors of the production and service sectors related to MICE tourism development; The need to pay attention to the socio-cultural development, awareness and community participation, the awareness of protecting cultural heritage, the environment, and scenic places at the destination requires educational institutions education, research institutions, cultural diversity, sports and recreation facilities. What many managers at the destinations have not yet paid attention to attract investment from these resources.

Currently, the development of Vietnam's MICE tourism model is very fast, through conferences and exhibitions, the income of organizers, venue suppliers and other topics of interest is increased, promote the development of industries, such as shopping, dining, accommodation, transportation, travel, etc. direct economic benefits and social benefits. In addition, MICE tourism's contribution to GDP mainly lies in conferences and exhibitions, which are directly driven by investment and consumer demand. For example, organizing exhibition activities must be drawn to the need for investment such as the construction of exhibition venues and related facilities, construction materials. At the same time, the process of organizing exhibitions leads to a growing demand for a wide range of products and services, such as conference and exhibition businesses serving, transportation, tourism, shopping, logistics and other related industries as well as related to the growing labor force needs.

\subsection{Research Hypothesis}

It is clear that MICE tourism contributes a lot of revenue to the tourism industry and influences the development of destinations and thereby influences regional economic growth that has been identified by many researchers such as Mistilisand Dwyer, 1999; Dwyer et al., 2000; McCartney, 2008; Campiranonand Arcodia, 2008. Besides, the above studies have not been clarified the effect of leadership capacity, resource destination mice to mice development and its 


\section{International Journal of Business Management and Economic Review}

Vol. 3, No. 01; 2020

ISSN: 2581-4664

impact on regional economic growth and that is also the basis for the author to build the following research model to fill the gaps of the previous studies.

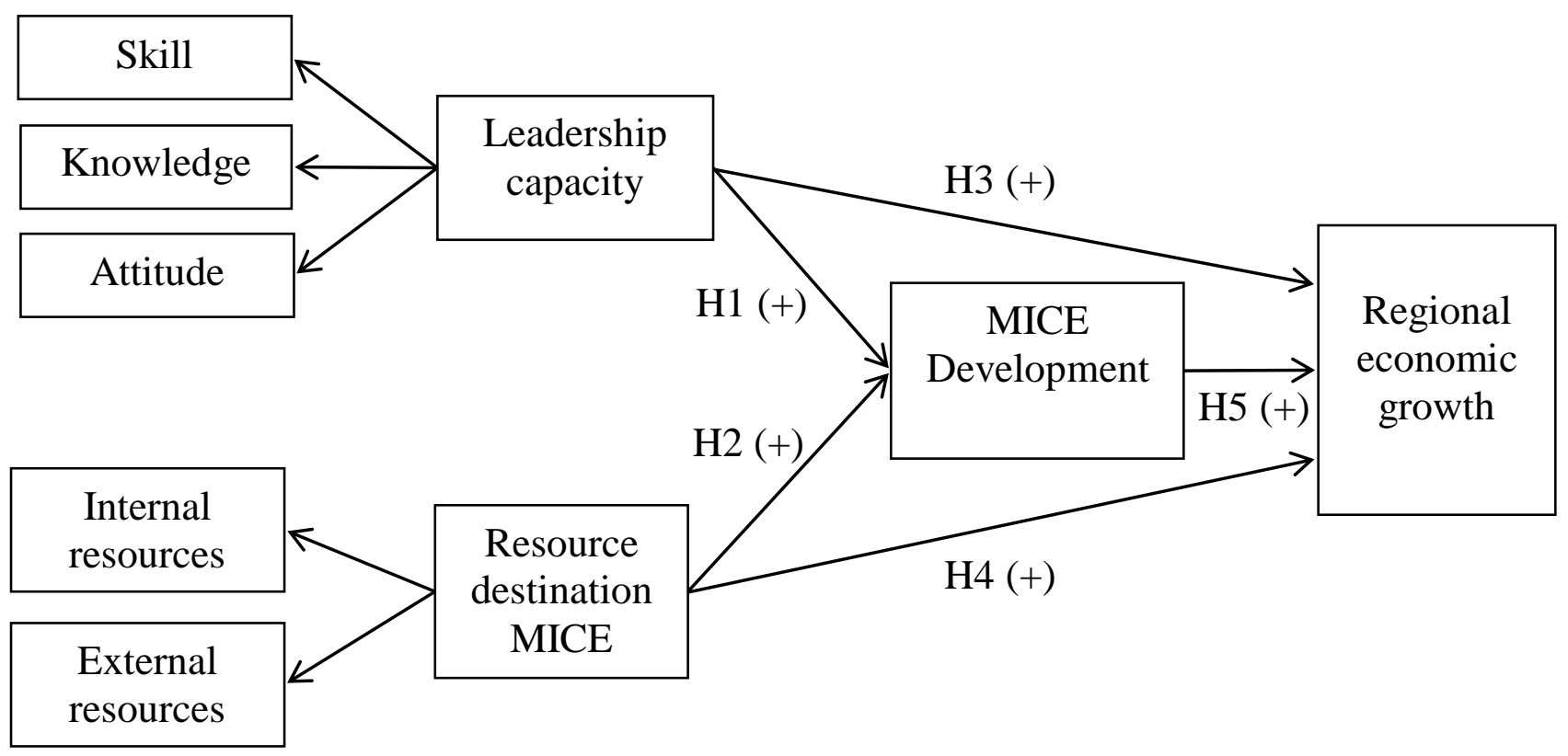

Source: Research of the author

Figure 1. Research Model

H1: Leadership capacity effect to MICE Development,

H2: Resource destination MICE effect to Development MICE,

H3: Leadership capacityimpact to Regional economic growth,

H4: Resource destination MICE impact to Regional economic growth,

H5: MICE Developmentimpact toRegional economic growth.

\section{RESEARCH METHOD}

The main object of the study is the effect of leadership capacity, resource destination mice to mice development and its impact on regional economic growth. Subjects surveyed in qualitative research are leaders, administrators, experts representing business organizations, Tourism Services related to MICE activities in mekong delta 13 provinces, Viet Nam (Long An, TienGiang, Ben Tre, KienGiang, HauGiang, Bac Lieu, Vinh Long, TraVinh, SocTrang, ĐongThap, Ca Mau, An Giangand Can Tho city), scientists specialized in business administration, tourism at some universities. Subjects of the survey in the official quantitative research through the 399 direct questionnaire include leaders of tourism businesses both domestically and abroad, providing MICE tourism services and leaders of the Department of Tourism, in 13 provinces in the Mekong Delta - Vietnam, during the 60 days from early July to September 2019. Data analysis techniques are Cronbach's Alpha reliability, exploratory factor 


\section{International Journal of Business Management and Economic Review}

Vol. 3, No. 01; 2020

ISSN: 2581-4664

analysis (EFA), affirmative factor factor (CFA), linear structure model test (SEM). Data analysis techniques using SPSS 22.0 and AMOS 22.0 software.

\section{RESULT}

\subsection{Measurement Model}

Analysis of the full stage of the SEM model is carried out by conducting suitability tests and statistical tests. The results of data processing for full analysis of SEM models are shown in figure 2 .

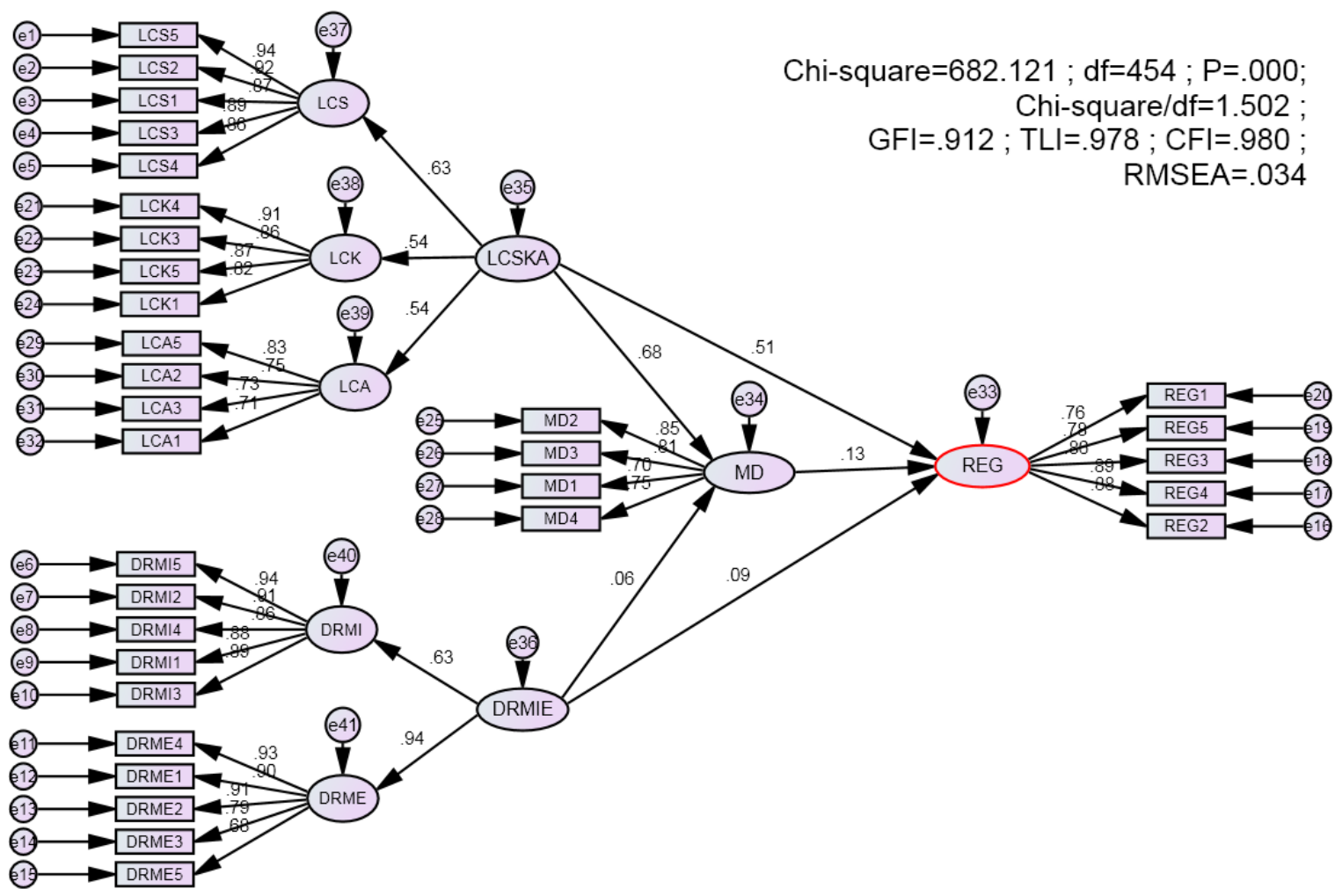

Source: Research results of the author

Figure 2: Standardized SEM results of the research model

\subsection{The Evaluation of Goodness of Fit Criteria}

Structural Equation Model (SEM) analysis requires the Goodness of Fit criteria to obtain accurate decision making. The results of evaluating the Goodness of Fit criteria can be seen in table 1 . 
International Journal of Business Management and Economic Review

Vol. 3, No. 01; 2020

ISSN: 2581-4664

Table 1. The goodness of Fit Measurement Model Criteria

\begin{tabular}{|l|l|l|l|}
\hline Size Index Criteria & Cut-off Value & Analysis Results & ModelEvaluation \\
\hline Chi-square & $\begin{array}{l}\text { Approaching zero with the } \\
\text { P-value (probability) does } \\
\text { not exceed 0.05. }\end{array}$ & $\begin{array}{l}682.121 \\
\text { P=0.000 }\end{array}$ & Good \\
\hline Chi-square/df & Default Model & 1.502 & Good \\
\hline $\begin{array}{l}\text { Baseline } \\
\text { Comparisons }\end{array}$ & Close to 1 & GFI $=0.912$ & TLI=0.978 \\
\hline RMSEA & $<0.050$ & CFI=0.980 & \\
\hline
\end{tabular}

Source: Research results of the author

The goodness of Fit criteria is relatively good, with the Chi-square value being at the limit of the probability value of 0.000 . Then the Chi-square/df value is less than 3.The GFI, TLICFIall of them have their respective numbers above 0.8 or close to 1 so that the model can also be said to be fit. Then in the Root Mean Square Error of Approximation (RMSEA) values are less than 0.05 so that the model is considered fit.

\subsection{Analysis of Influence between Variables}

Table 2.Estimate Standardized Regression Weights Influence Between Variables

\begin{tabular}{|l|l|l|l|l|l|l|l|}
\hline & & & Estimate & S.E. & C.R. & P & Result \\
\hline MD & $<---$ & LCSKA & 0.683 & 0.146 & 7.618 & $* * *$ & Accept H1 \\
\hline MD & $<---$ & DRMIE & 0.063 & 0.081 & 1.273 & 0.003 & Accept H2 \\
\hline REG & $<---$ & LCSKA & 0.508 & 0.206 & 4.268 & $* * *$ & Accept H3 \\
\hline REG & $<---$ & DRMIE & 0.088 & 0.084 & 1.834 & $* * *$ & Accept H4 \\
\hline REG & $<---$ & MD & 0.134 & 0.101 & 1.415 & 0.027 & Accept H5 \\
\hline
\end{tabular}

Source: Research results of the author

Testing the hypothes is H1: The hypothesis H1 Leadership capacity has a positive influence on MICE Development. The results of SEM analysis show that the non-standardized regression coefficient and the positive sign (+) show the positive relationship between Leadership capacity and MICE Development. With significance level $\mathrm{P}=0.000$; coefficient $\beta=0.683$; $\mathrm{SE}=0.146$, meaning hypothesis $\mathrm{H} 1$ is accepted by empirical data.

Testing the hypothesis H2: Hypothesis H2 Resource destination MICE effect to Development MICE. From the results of SEM analysis, it shows that the normalized regression coefficient is zero and bears a positive sign (+) showing the positive relationship between Resource destination MICE effect to Development MICE. With significance level $\mathrm{P}=0.003$; coefficient $\beta=0.063$; SE $=0.081$, meaning that hypothesis $\mathrm{H} 1$ is accepted by empirical data.

Testing the hypothesis H3: Hypothesis H3 Leadership capacity impact to Regional economic growth. The results of SEM analysis show that the non-standardized regression coefficient and positive sign (+) show the positive relationship between Leadership capacity impact to Regional economic growth. With significance level $\mathrm{P}=0.000$; coefficient $\beta=0.508 ; \mathrm{SE}=0.206$, meaning 


\section{International Journal of Business Management and Economic Review}

Vol. 3, No. 01; 2020

ISSN: 2581-4664

that hypothesis $\mathrm{H} 1$ is accepted by empirical data.

Testing the hypothesis H4: Hypothesis H4 Resource destination MICE impact to Regional economic growth.The results of SEM analysis show that the non-standardized regression coefficient and positive sign (+) show the positive relationship between Resource destination MICE impact to Regional economic growth. With significance level $\mathrm{P}=0.000$; coefficient $\beta=$ $0.088 ; \mathrm{SE}=0.084$, meaning hypothesis $\mathrm{H} 1$ is accepted by empirical data.

Testing the hypothesis H5: The hypothesis H5 MICE Development impact to Regional economic growth. The results of SEM analysis show that the non-standardized regression coefficient and positive sign (+) represent the positive relationship between MICE Development impact to Regional economic growth. With significance level $\mathrm{P}=0.027$; coefficient $\beta=0.134$; $\mathrm{SE}=0.101$, meaning that hypothesis $\mathrm{H} 1$ is accepted by empirical data.

\section{CONCLUSIONS}

Through the research results achieved statistical significance the effect of leadership capacity, resource destination mice to mice development and its impact on regional economic growth in Mekong delta provinces, Vietnam.

Although the research has significant and theoretical contributions, it still contains the following limitations:

Firstly, although according to the results of standardized estimation, the official squared correlation index is equal to 0.71996 which means that the model that explains $71.996 \%$ is relatively high.However, there may still be some other potential factors affecting regional economic growth are not yet included in this research model. Further studies need to consider additional factors to increase the interpretation of the research model.

Secondly, the sample of only 399 is not large and only collected in Mekong delta provinces, Vietnam, so the results of the study cannot be generalized reducing the errors during testing as well as the errors of the research model should expand the scope of the study.

Thirdly, the research data needs to supplement secondary data, thereby offering some solutions for businesses and recommendations to the State to create a boost for MICE tourism for sustainable development as well as the growth rate economic growth for the region.

\section{REFERENCES}

Acedo, F. J., Barroso, C., \& Galan, J. L. (2006). The resource-based theory: dissemination and main trends. Strategic management journal, 27(7), 621-636.

Bass, B. M. (1990). From transactional to transformational leadership: Learning to share the vision. Organizational dynamics, 18(3), 19-31.

Campiranon, K., \&Arcodia, C. (2008). Market segmentation in time of crisis: A case study of the MICE sector in Thailand. Journal of Travel \& Tourism Marketing, 23(2-4), 151-161.

Dwyer, L., Deery, M., Jago, L., Spurr, R., \&Fredline, L. (2007).Adapting the tourism satellite account conceptual framework to measure the economic importance of the meetings industry. Tourism Analysis, 12(4), 247-255.

Dwyer, L., Mellor, R., Mistilis, N., \& Mules, T. (2000).A framework for assessing "tangible" and "intangible" impacts of events and conventions. Event management, 6(3), 175-189. 


\section{International Journal of Business Management and Economic Review}

Vol. 3, No. 01; 2020

ISSN: 2581-4664

Dwyer, L., Mistilis, N., Forsyth, P., \&Rao, P. (2001).International price competitiveness of Australia's MICE industry. International Journal of Tourism Research, 3(2), 123-139.

Fan, H. (2017, October).An empirical study on the relationship between the development of MICE industry and regional economic growth. In Second International Conference On Economic and Business Management (FEBM 2017). Atlantis Press.

Gregorić, M. (2014, May).PESTEL analysis of tourism destinations in the perspective of business tourism (MICE). In 22nd International Congress, Tourism \& Hospitality Industry 2014, Trends in Tourism and Hospitality Management.

Harrison, D. (2015). Development theory and tourism in developing countries: what has theory ever done for us?. International Journal of Asia Pacific Studies, 11(S1), 53-82.

Koenigsfeld, J. P., Kim, S., Cha, J., Perdue, J., \&Cichy, R. F. (2012). Developing a competency model for private club managers. International Journal of Hospitality Management, 31(3), 633-641.

McCabe, V., Poole, B., Weeks, P., \&Leiper, N. (2000).The business and management of conventions.

McCartney, G. (2008). Key considerations in adopting tourism as a destination development strategy. Euro Asia Journal of Management, 18(1), 51-61.

Mills, J., Platts, K., \& Bourne, M. (2003).Applying resource-based theory. International Journal of Operations \& Production Management.

Mistilis, N., \& Dwyer, L. (1999). Tourism gateways and regional economies: the distributional impacts of MICE. International Journal of Tourism Research, 1(6), 441-457.

Sylla, M., Chruściński, J., Drużyńska, P., Płóciennik, P., \&Osak, W. (2015).Opportunities and Limitations for MICE Tourism Development in Łódź. Turyzm, 25(2), 117-124. 